\title{
Relative toxicity of some commonly used agro- chemicals against a fresh water fish species, catla catla (ham.)
}

\begin{abstract}
The bioassays were conducted with five insecticides to determine their comparative toxicity to the carp of fresh water fish, Catla catla (Ham.). There was a variation in lethal time of these compounds and the values ranging from 12.57 to 46.24 minutes. Of these compounds tested, Oxydemeton-methyl $25 \% \mathrm{EC}$ was the most toxic followed by Monocrotophos 36\% SL, Chlorpyriphos 20\% EC and Profenofos $50 \%$ EC while Azadirectin (neem formulation) exerted least effect.
\end{abstract}

Volume 8 Issue 6 - 2018

\author{
Palash Mondal, Bholanath Mondal \\ Department of Plant Protection, India
}

\begin{abstract}
Correspondence: Bholanath Mondal, Department of Plant Protection, Palli-Siksha Bhavana (Institute of Agriculture),VisvaBharati, Sriniketan 73I 236, West Bengal, India, Email bhalanath.ppvb@gmail.com
\end{abstract}

Received: March 17, 2018 | Published: November 16, 2018

\section{Introduction}

Humans have long interfered in nature by extracting natural resources and discarding residues into the environment. This impact has been intensified since the Industrial Revolution with many chemicals now being released into aquatic and terrestrial ecosystems as well as the atmosphere. ${ }^{1}$ Pesticides, while of undeniable value to agriculture, are also significant agents of environmental impact. Frequently, pesticidal contamination has been found in environments, elements of the food chain and humans ${ }^{2}$ as these Chemical pollutants enter water bodies as a consequence of rain and leaching from the soil, ${ }^{3}$ or because it is carelessly discharged directly into aquatic ecosystems. Therefore, the aquatic organisms may show its toxic effects. Toxic effects can be sensed immediately after exposure to toxicants or when followed by a lag. These effects are determined by the toxicological characteristics of the substance and the ability of the organisms to metabolize it. Some toxic effects in aquatic biota are reversible, whereas some others are not, leading the organisms to mortality. In many cases, toxic effects are reversible only if the organisms can escape the toxicant and migrate to an uncontaminated environment. ${ }^{4}$

Toxicity tests using early life stages of fish are of great importance in assessing risks to growth, reproduction and survival in polluted environments and are important tools for good environmental monitoring. ${ }^{5,6}$ Such tests indicate those compounds that should be carefully monitored for potential hazards to fishes as they have great importance for food and their commercial values. Among different species of fish present in the fresh water surface body, Catla catla (Ham.) was reported to be more susceptible to water pollution. Therefore, an investigation was carried out to find out the toxic effect of some commonly used agro-chemicals against this fresh water fish species at much lower concentration than recommended field doses for insect control.

\section{Materials and methods}

Ten carps of $C$. catla of range between $12-15 \mathrm{~g}$ were used in each test concentration and in the untreated control. The fishes were released in each glass jar containing one litre of insecticide solution which was prepared by serial dilution. Four organophosphate insecticides (Profenofos 50\% EC, Oxydemeton-methyl 25\% EC, Chlorpyriphos $20 \%$ EC and Monocrotophos 36\% SL) and one neem formulation (Azadirachtin $0.15 \% \mathrm{EC}$ ) along with a control were used for bioassay studies. At first, stock solutions were prepared by adding respective recommended field doses of the insecticides in one litre of water and from the stock solutions final concentrations viz 50, 25, $12.56 .25 \mathrm{ppm}$ were made for the bioassay study. The reactions of the fish were recorded at 10minutes intervals for one hour. From the mortalities in different treatments at different time intervals $\mathrm{LT}_{50}$ values were calculated by Probity analysis, ${ }^{7}$ because this statistical estimate provides a basis for evaluating and comparing the relative toxicity of pesticides used for the experiment. The experiment was carried out at room temperature and $\mathrm{LT}_{50}$ values at highest concentrations of different formulations of insecticide have been recorded.

\section{Results and discussion}

The relative toxicity of the different agro-chemicals varied against C. catla. The toxicity of the Oxydemeton-methyl $25 \%$ EC was maximum followed by Monocrotophos 36\% SL, Chlorpyriphos 20\% EC and Profenofos 50\% EC. The least toxicity was exerted by name formulation. The median lethal time for the above agro-chemicals was $12.57,13.94,14.99,17.58$ and 46.24minutes, respectively (Table 1). The toxicity of carbaryl, a carbamate insecticide and its metabolite, 1-naphthol, to four species of fish was studied by Tilak et al. ${ }^{8}$ The calculated $\mathrm{LC}_{50}$ values of carbaryl for $C$. catla, Anabas testudineus (Bloch), Mystus cavasius (Ham.) and M. vittatus (Bloch) were 6.4, 6.6, 4.6 and 2.4ppm, respectively, and that of 1-naphthol were 4.3,3, 0.33 and 1.ppm, respectively.

At the present time, there are no magic numbers to plug into a formula for the estimation of a so-called "safe concentration" from static, acute toxicity bioassays. Subacute and chronic studies utilizing both fish and other such organisms are necessary to determine sublethal effects. The significant physiological effects on these organisms may be used for the development of water quality criteria for aquatic life. 
The hazard of a pesticide to aquatic life depends upon the degree of its use and toxicity. The relative toxicity values reported in the present

Table I Median lethal time of different agro-chemicals against $C$. catla investigation indicated that most of these pesticides were extremely toxic and could be considered hazardous for aquatic life.

\begin{tabular}{|c|c|c|c|c|c|}
\hline Insecticides & Field dose & $\begin{array}{l}\text { Highest } \\
\text { concentration }\end{array}$ & Regression equation & $\begin{array}{l}\text { Heterogenecity c2 } \\
(p=0.05)\end{array}$ & $\begin{array}{l}\text { LT50 (Min.) (Fiducial } \\
\text { limits) }\end{array}$ \\
\hline $\begin{array}{l}\text { Profenofos } \\
50 \% \mathrm{EC}\end{array}$ & $\begin{array}{l}2 \mathrm{ml} / 1 \\
(=2000 \mathrm{ppm})\end{array}$ & $50 \mathrm{ppm}$ & $Y=-0.251+4.225 X$ & 1.67 & $17.58(11.77-23.22)$ \\
\hline $\begin{array}{l}\text { Oxydemeton-methyl } \\
25 \% \text { EC }\end{array}$ & $\begin{array}{l}1 \mathrm{ml} / 1 \\
(=1000 \mathrm{ppm})\end{array}$ & $50 \mathrm{ppm}$ & $Y=0.484+4.106 X$ & 3.12 & $12.57(6.58-16.81)$ \\
\hline $\begin{array}{l}\text { Chlorpyriphos } \\
20 \% \text { EC }\end{array}$ & $\begin{array}{l}2.5 \mathrm{ml} / 1 \\
(=2500 \mathrm{ppm})\end{array}$ & 50ppm & $Y=0.876+3.506 X$ & 1.46 & $14.99(5.97-23.84)$ \\
\hline $\begin{array}{l}\text { Monocrotophos } 3 \% \\
\text { SL }\end{array}$ & $\begin{array}{l}1.5 \mathrm{ml} / 1 \\
(=1500 \mathrm{ppm})\end{array}$ & 50ppm & $\mathrm{Y}=0.408+4.011 \mathrm{X}$ & 0.53 & $13.94(7.49-19.03)$ \\
\hline $\begin{array}{l}\text { Azadirachtin } \\
0.15 \% \mathrm{EC}\end{array}$ & $\begin{array}{l}1.5 \mathrm{ml} / 1 \\
(=1500 \mathrm{ppm})\end{array}$ & $50 \mathrm{ppm}$ & $Y=1.524+2.087 X$ & 0.28 & $46.24(21.08-101.44)$ \\
\hline
\end{tabular}

\section{Acknowledgements}

None.

\section{Conflict of interest}

Author declares that there is no conflict of interest.

\section{References}

1. Ochiai EI. Toxicity of heavy metals and biological defense. Principles and Applications in bioinorganic chemistry - VII. Journal of Chemical Education. 1995;72(6):479.

2. Rodrigues EL. Alterações morfológicas em hepatócitos de Brachydanio rerio (Hamilton-Buchanan, 1822; 1823) exposto à ação do organofosforado dimetoato $500 \mathrm{em}$ dose subletal. Dissertação de Mestrado, Universidade Federal do Paraná, Curitiba; 1994. 76 p.

3. Kumar K, Ansari BA. Malathion toxicity: skeletal deformities in zebrafishes (Brachydanio rerio, cyprinidae). Pestic Sci. 1984.
4. Rand GM, Wells PG, McCarty LS. Introduction to aquatic toxicology. In: Rand GM, editor. Fundamentals of Aquatic Toxicology -Effects, Environmental Fate, and Risk Assessment. Washington, DC: Taylor and Francis Publishers; 1995. p. 3-67.

5. Zagatto PA. Mini-curso: ecotoxicologia aquática". VII Congresso Brasileiro de Limnologia. Florianópolis: SBL; 1999. 124 p.

6. Kristensen P. Sensitivity of embrios and larvae in relation to other stages in the life cycle of fish: a literature review. In: Muller R, Lloyd R, editors. Sublethal and cronic effects of pollutants on freshwater fish. United Nation Organization: Fishing News Books; 1994. p. 339-352.

7. Finney DJ. Probit Analysis. 3rd ed. London: Cambridge University press; 1971.

8. Tilak KS, Rao DM, Devi AP. Toxicity of Carbaryl and 1-Naphthol to Four Species of Freshwater Fish. J Biosci. 1981;3(4):457-462. 